\title{
Establishment risk from pet-trade freshwater turtles in the European Union
}

\author{
O. Kopecký(1),^, L. Kalous ${ }^{(1)}$, J. Patoka ${ }^{(1)}$
}

Received January 29, 2013

Revised May 23, 2013

Accepted May 28, 2013

Key-words: pet market, Czech Republic, introduction

pathway, invasive species, climate

\section{ABSTRACT}

The pet-turtle market has grown in recent years and become an important pathway for the introduction of alien species in Europe. The import of Trachemys scripta elegans has been banned by European Commission Regulation due to its species' expanding territory and negative impact on native species. Since the demand from hobby breeders persists, however, blocking imports of this popular subspecies opens up the possibility for the introduction of other potentially invasive turtles. We determined those turtle species most common in the pet trade within the Czech Republic, which is the most important producer, importer and exporter of ornamental aquatic animals in the EU. The determination of establishment risk for the EU as a whole was then individually evaluated for turtle species based on known establishment models. Chelydra serpentina, Apalone spinifera, Apalone mutica, and Sternotherus odoratus were considered most problematic, because these species have serious establishment risk and are imported to the EU in substantial numbers. Also localities in the EU were identified where probability is highest for establishment of non-native turtles.

\section{RÉSUMÉ}

Le risque d'implantation des tortues d'eau douce, issues du commerce d'animaux de compagnie, dans l'Union européenne

Mots-clés : marché des animaux de compagnie, République tchèque, voie d'introduction, espèces envahissantes, climat
Le marché des tortues de compagnie a augmenté ces dernières années et devient une voie importante pour l'introduction d'espèces exotiques en Europe. L'importation de Trachemys scripta elegans a été interdite par le règlement européen en raison du territoire d'expansion de cette espèce et de son impact négatif sur les espèces indigènes. Depuis, la demande des éleveurs amateurs persiste, et l'interdiction de l'importation de cette sous-espèce populaire ouvre la possibilité pour l'introduction d'autres tortues potentiellement envahissantes. Nous avons déterminé les espèces de tortue les plus courantes dans le commerce des animaux de compagnie au sein de la République tchèque, qui est le plus important producteur, importateur et exportateur d'animaux aquatiques ornementaux dans I'UE. La détermination du risque d'implantation dans I'UE dans son ensemble a ensuite été évalué individuellement pour les espèces de tortues sur la base de modèles d'implantation connus. Chelydra serpentina, Apalone spinifera, Apalone mutica, et Sternotherus odoratus ont été considérées comme les plus problématiques, car ces espèces ont un risque d'implantation sérieux et sont importées dans l'UE en nombre substantiel. De plus, les lieux dans I'UE où la probabilité est la plus forte pour l'établissement des tortues non indigènes, ont été identifiés.

(1) Czech University of Life Sciences Prague, Faculty of Agriculture, Food and Natural Resources, Department of Zoology and Fisheries, Kamýcká 129, 16521, Prague 6 - Suchdol, Czech Republic

* Corresponding author: kopeckyo@af.czu.cz 


\section{INTRODUCTION}

Alien invasive species are among the major causes of biodiversity loss (Dukes and Mooney, 1999; Strayer et al., 2006; Ricciardi, 2007), and conservation agencies around the world devote various degrees of attention to this phenomenon (Hulme, 2006). Time, money and considerable effort are spent each year in eradication, control and mitigation of alien species impacts (Pimentel et al., 2005), mainly for reasons that these invaders may displace native species from their ecological niches through 1) competition for resources, 2) hybridization, 3 ) introduction of pathogens, or 4) predation (Williamson, 1996; Manchester and Bullock, 2000; Kraus, 2009).

In contrast to plants, the invasiveness of animals, and especially vertebrates, has attracted much less attention in the past (Pyšek et al., 2010). Reptiles, in particular, have been widely overlooked in systematic invasion studies (Kraus, 2009; Bomford et al., 2009; Henderson et al., 2011), and their establishment potential and invasion dynamics remain poorly understood (Ernst et al., 2011). Delivering Alien Invasive Species Inventory for Europe - DAISIE (2012) recognizes in Europe 72 alien reptile species. While not all of these reptiles are exotic to Europe, many of them, such as the European pond turtle (Emys orbicularis) and slow worm (Anguis fragilis), were translocated within the continent into several countries where they are not native (McGuire and Marnell, 2000; Mlíkovský and Stýblo, 2006; Kark et al., 2009).

Turtles, which constitute a relatively species-poor order, comprise the group with the globally highest number of introduction events among reptiles (Kraus, 2009). It is not surprising, therefore, that the highest densities of alien reptiles in Europe are found in aquatic habitats (Pyšek et al., 2010), and 13 of 17 species of introduced alien turtles are of freshwater origin (DAISIE, 2012).

Turtles of the family Emydidae - with 2,108 recorded introduction events - are the most commonly introduced reptile taxon in the world. Within Emydidae, moreover, $68 \%$ of the aforementioned introduction events involve pond sliders (Trachemys scripta) (Kraus, 2009). This species is taxonomically sorted into three subspecies (Fritz and Havaš, 2007) from which the red-eared slider (Trachemys scripta elegans) is the most common subspecies with the greatest native range, encompassing the Mississippi Valley in the USA and northern parts of Mexico (Ernst et al., 1994).

Mainly due to its appearance, T. s. elegans is also one of the most popular reptile pets worldwide (Franke and Telecky, 2001). When it reaches adulthood, however, it loses its attractive coloration, and hobby keepers often release their turtles into local waters (Cadi and Joly, 2003). At these locations, the released individuals may indirectly exclude or outcompete native turtle species (Cadi and Joly, 2003; Cadi and Joly 2004; Polo-Cavia et al., 2008) and can indeed negatively affect other species in aquatic communities (Mlíkovský and Stýblo, 2006; Teillac-Deschamps and Prevot-Julliard, 2006; Pešát, 2008). Therefore the import of T. s. elegans was banned by the EU's Commission Regulation No 338/1997 (EC, 1997). However southern and western states of the European Union (EU) have already established vital populations of $T$. s. elegans including Spain (Martínez-Silvestre et al., 1997), France (Cadi et al., 2004), and Italy (Sindaco et al., 2006). Although it seems reasonable to stop import of the pond slider, this does open up the possibility for introduction of other invasive species, inasmuch as the demand for aquatic turtles by hobby keepers still persists. Since 1997, other species of turtles may have met the market demand while replacing $T$. s. elegans in the EU pet trade, but, due to a lack of information (among other factors), these turtles may pose the same problem as the forbidden $T$. s. elegans.

Identifying the potential danger posed by alien species and then preventing new introductions is currently considered the most effective management approach (Mack et al., 2000; Thuiller et al., 2005; Keller et al., 2008). In accordance with this view, we determined which turtle species are now most common in the pet trade and their trade quantities. Data from the Czech Republic authorities were utilized, since the Czech Republic is the main producer, importer and exporter of aquatic ornamental animals in the EU (Livengood and Chapman, 2007; Miller-Morgan, 2009; Peay, 2009). Establishment risk for the EU as a whole was then 
evaluated individually for important turtle species within the pet trade based upon a known establishment model (Bomford, 2008; Bomford et al., 2009).

The present paper aims to highlight the possible problems with imports of other turtle species which should be regulated at EU level as is the case for $T$. s. elegans. The relationship among zoogeographical or family origin with obtained establishment risk ranks was additionally tested.

\section{METHODS}

\section{> EXAMINING DATA ON TURTLE IMPORTS}

Under Czech Republic laws and regulations, the importation of animals and their products is subject to reporting to the Customs Administration as well as the State Veterinary Administration. We used more precise data from the Veterinary Administration, where importers' requests for import authorization are evaluated and processed. Information about species or genera of live turtles imported into the Czech Republic is available since 2008. While these data represent issued permits, the actual numbers of imported individuals might be smaller because shipments do not always reach the maximum permitted quantity due to supply issues. Nevertheless, the true numbers may not be larger than those quantities stated in the permits (Zhou and Jiang, 2008). On the other hand, it cannot be excluded that other individuals entered EU via the black market but true numbers are obviously unknown. The proportions of the various turtle species imported were approximated based on interviews with six important wholesalers in the Czech Republic that are known to be the main importers of live turtles. The information thus obtained was combined with that from the permits and the imported numbers of each species per year were accordingly estimated.

\section{> DETERMINATION OF ESTABLISHMENT RISK FOR EU}

We used a model designed by Bomford (2008) and Bomford et al., (2009), which is based on parameters: (i) climatic similarity of source (native distribution of species) and target regions (termed climate match risk score), (ii) species' ability to establish populations elsewhere (termed prop.species value), (iii) establishment success of the other species from the same family (termed family random effect), and constant value characteristic (iv) jurisdiction score, which accounts for expected variability in establishment success rate due to the effect of particular jurisdiction (country, state or province).

Climate match risk scores were computed using the program Climatch v1.0 (Bureau of Rural Sciences, 2008). A Euclidean algorithm and 16 temperature and rainfall variables with sum of scores for classes 6-10 was used (Bomford, 2008).

Due to fact that some introductions events occurred after 2008, we cannot take original prop.species values from Bomford (2008). Therefore values of prop.species scores were computed anew for this study using the Kraus (2009) database and following instructions given by Bomford (pers. comm.). When values for calculating prop.species or prop.genus were insufficient (i.e. fewer than 3 introduction attempts), we did not compute a prop.family value (Henderson et al., 2011) but instead used approximation according to phylogenetically related genera (i.e. the closest branches on an up-to-date turtle phylogenetic tree (Guillon et al., 2012)).

Family random effect was taken from Bomford (2008).

As the target region we utilized all states of the EU, including the autonomous islands of Macaronesia (namely the Azores, Madeira, and Canary Islands) in a manner similar to Arnold (2003), while, due to their geographical remoteness, the overseas departments and regions of France were not included into our study as parts of the EU. The target region contained 1113 climate stations. The jurisdiction data for the entire EU did not exist and no jurisdiction score is available for the EU as a whole. Therefore we used a combined jurisdiction score, 
Table I

Estimated annual numbers of the most marketed turtle species imported by pet wholesalers into the Czech Republic during 2008-2012.

\begin{tabular}{|l|c|c|c|c|c|c|c|}
\hline Species & 2008 & 2009 & 2010 & 2011 & 2012 & sum & origin \\
\hline Trachemys scripta & 28000 & 59900 & 44000 & 38500 & 41200 & $\mathbf{2 1 1 6 0 0}$ & USA \\
\hline Graptemys pseudogeographica & 15000 & 27500 & 23500 & 23000 & 26000 & $\mathbf{1 1 5 0 0 0}$ & USA \\
\hline Sternotherus odoratus & 9000 & 26060 & 21000 & 11120 & 10762 & $\mathbf{7 7 9 4 2}$ & USA \\
\hline Pseudemys concinna & 9000 & 22000 & 20000 & 10000 & 10600 & $\mathbf{7 1 6 0 0}$ & USA \\
\hline Pseudemys peninsularis & 9000 & 20135 & 20012 & 11000 & 10000 & $\mathbf{7 0 1 4 7}$ & USA \\
\hline Sternotherus carinatus & 4000 & 10800 & 16010 & 11050 & 7600 & $\mathbf{4 9 4 6 0}$ & USA \\
\hline Apalone ferox & 4000 & 5035 & 10000 & 5006 & 3500 & $\mathbf{2 7 5 4 1}$ & USA \\
\hline Apalone spinifera & 4000 & 5035 & 10000 & 5000 & 3000 & $\mathbf{2 7 0 3 5}$ & USA \\
\hline Apalone mutica & 4000 & 5000 & 10000 & 5000 & 3000 & $\mathbf{2 7 0 0 0}$ & USA \\
\hline Chelydra serpentina & 500 & 1170 & 1280 & 1767 & 500 & $\mathbf{5 2 1 7}$ & USA \\
\hline Mauremys sinensis & 1000 & 250 & 2400 & 1000 & 0 & $\mathbf{4 6 5 0}$ & Taiwan \\
\hline Pelodiscus sinensis & 1000 & 0 & 0 & 0 & 0 & $\mathbf{1 0 0 0}$ & Taiwan \\
\hline Kinosternon scorpioides & 10 & 50 & 37 & 195 & 550 & $\mathbf{8 4 2}$ & USA \\
\hline Platemys platycephala & 60 & 40 & 37 & 60 & 600 & $\mathbf{7 9 7}$ & Surinam \\
\hline Malaclemys terrapin & 500 & 70 & 0 & 0 & 0 & $\mathbf{5 7 0}$ & USA \\
\hline
\end{tabular}

Note: Listed are only species with sum of more than 500 imported individuals. Data from 2012 are for January-September only. Trachemys scripta species include only subspecies scripta and troostii.

based on published values for previously tested countries or states (Bomford, 2008; Bomford et al., 2009). Before we applied our modification, the model was calibrated on Trachemys scripta scripta for EU and we got presumable serious risk rank.

\section{> STATISTICS}

For testing the dependence of establishment risk for the EU upon zoogeographical and family origin, we used only risk ranks from the model. Risk ranks were evaluated as low $=0$, moderate $=1$, serious $=2$, and extreme $=3$. When risk rank categories had ranges, we used the mean value. Due to a great number of categories ( 6 zoogeographical regions, 9 families) and low number of dependent variables (34 turtle species), we used separate non-parametric Kruskal-Wallis tests. To determine if there is a balanced, market offer of turtles from different zoogeographical regions or families, we computed chi-square tests of homogeneity (observed vs. balanced expected values). Tests were computed using Statistica 10 (Statsoft, 2010). We used $\alpha=0.05$ to evaluate statistical significance.

\section{> RESULTS}

Based on data from the Czech Republic (Table I) we postulate that species of turtles imported into the EU in substantial numbers are Trachemys scripta (subspecies scripta and troosti), Graptemys pseudogeographica, Sternotherus odoratus, Pseudemys concinna and Pseudemys peninsularis. Turtle origins were not evenly distributed among zoogeographical regions $\left(\chi^{2}=33.42, d f=5, P<0.001\right)$, which is true also for turtle families $\left(\chi^{2}=17.36, d f=8\right.$, $P<0.05)$. Most species were from the Nearctic zoogeographical area (53\%) and Emydidae family (29\%). The results from the model (Table II), revealed no differences among families $(K-W$ test, $d f=8, H=11.88, P=0.16)$ or zoogeographical regions $(K-W$ test, $d f=5$, $H=1.12, P=0.95)$ in ranks for establishment risk. 


\section{Table II}

Results of computed establisment risk model for individual species of turtles imported to EU. Conversion of establishment risk score to establishment risk ranks follows set up values: low $\leqslant 0.16$, moderate $0.17-$ 0.39 , serious $0.40-0.85$, extreme $\geqslant 0.86$.

\begin{tabular}{|c|c|c|c|}
\hline Species & Family & Risk score & Risk rank \\
\hline Pelomedusa subrufa & Pelomedusidae & 0.51 & serious \\
\hline Pelusios sinuatus & Pelomedusidae & 0.24 & moderate \\
\hline Pelusios subniger & Pelomedusidae & 0.11 & low \\
\hline Podocnemis unifilis & Podocnemididae & $0.03-0.40$ & low - serious \\
\hline Hydromedusa tectifera & Chelidae & $0.15-0.78$ & low - serious \\
\hline Chelodina reimanni & Chelidae & $0.05-0.49$ & low - serious \\
\hline Macrochelodina rugosa & Chelidae & $0.05-0.49$ & low - serious \\
\hline Platemys platycephala & Chelidae & $0.11-0.72$ & low - serious \\
\hline Chelus fimbriatus & Chelidae & $0.16-0.79$ & low - serious \\
\hline Chelydra serpentina & Chelydridae & 0.83 & serious \\
\hline Carettochelys insculpta & Carrettochelyidae & $0.02-0.27$ & low - moderate \\
\hline Apalone ferox & Trionychidae & 0.27 & moderate \\
\hline Apalone mutica & Trionychidae & 0.49 & serious \\
\hline Apalone spinifera & Trionychidae & 0.75 & serious \\
\hline Pelodiscus sinensis & Trionychidae & 0.32 & moderate \\
\hline Kinosternon baurii & Kinosternidae & 0.06 & low \\
\hline Kinosternon scorpioides & Kinosternidae & 0.06 & low \\
\hline Kinosternon subrubrum & Kinosternidae & 0.16 & low \\
\hline Sternotherus odoratus & Kinosternidae & 0.64 & serious \\
\hline Sternotherus carinatus & Kinosternidae & 0.19 & moderate \\
\hline Clemmys guttata & Emydidae & 0.13 & low \\
\hline Chrysemys picta & Emydidae & 0.34 & moderate \\
\hline Graptemys geographica & Emydidae & 0.28 & moderate \\
\hline Graptemys pseudogeographica & Emydidae & 0.06 & low \\
\hline Malaclemys terrapin & Emydidae & 0.05 & low \\
\hline Pseudemys concinna & Emydidae & 0.12 & low \\
\hline Pseudemys nelsoni & Emydidae & 0.06 & low \\
\hline Pseudemys peninsularis & Emydidae & 0.05 & low \\
\hline Pseudemys rubriventris & Emydidae & 0.06 & low \\
\hline Trachemys scripta & Emydidae & 0.36 & moderate \\
\hline Cyclemys dentata & Geoemydidae & 0.07 & low \\
\hline Mauremys reevesii & Geoemydidae & 0.09 & low \\
\hline Mauremys sinensis & Geoemydidae & 0.05 & low \\
\hline Rhinoclemmys pulcherrima & Geoemydidae & 0.05 & low \\
\hline
\end{tabular}

Note: We present range of values of establishment risk scores for families Carettochelyidae, Chelidae, Podocnemididae due to the absence of the family random effect (Bomford, 2008).

No introduction of Carettochelys insculpta is known, moreover this species belongs to monotypic family, therefore it was not possible to compute prop.species value due to specific environment demands (Doody et al., 2003) therefore we decided to set it as 0.

Trachemys scripta species includes only subspecies scripta and troosti.

Number of imported individuals (more than 500 individuals among 2008-2012) (Table I) combined with establishment risk (serious and extreme risk rank) (Table II), suggests that reproduction will be recorded in the future in the following species: Sternotherus odoratus, Apalone spinifera, Apalone mutica and Chelydra serpentina. 


\section{DISCUSSION}

The pet trade is growing in intensity globally, and its contribution to new introductions of amphibians and reptiles exceeds by almost four times any other recognizable pathway (Kraus, 2009). Hence, pet-trade species of amphibians and reptiles also have the highest absolute numbers among species established worldwide (Kraus, 2009).

Generally, introduced species are successful in establishing new populations or invading within non-native ranges only when a combination of several variables is favourable. These are 1) propagule pressure, also recognized as introduction effort (Lockwood et al., 2005; Simberloff, 2009; Wilgen and Richardson, 2012); 2) biotic factors like life history, but also including presence of predators, pathogens and competitors (Bomford, 2003; Strauss et al., 2006; Proches et al., 2008); and 3) abiotic factors, especially the climatic similarity of the native and non-native ranges (Thuiller et al., 2005; Hayes and Barry, 2008; Bomford et al., 2009).

In the models by Bomford (2008), and partially Bomford et al. (2009) used in this study, biotic and abiotic factors were taken into account. Biotic factors are represented by the variables prop.species value and family random effect. Abiotic factors are included into the climate match risk score, which reflects similarity of native and non-native range in terms of temperature and rainfall variables. We do not incorporate propagule pressure into the models, which can be viewed as a weakness of our approach. Although the propagule pressure is considered to be a major factor in establishment or invasion studies (Lockwood et al., 2005; Bomford et al., 2009; Simberloff, 2009; Wilgen and Richardson, 2012), precise information about the number of released individuals is rarely available (Kolar and Lodge, 2001; Hayes and Barry, 2008; Bomford et al., 2009). In accordance with Copp et al. (2010), however, the data on turtle imports presented in Table I can be used as a roughly correlating measure for propagule pressure, although we are cognizant of the approximate value of the presented data. Such correlation between high propagule pressure and imports can be seen in the example of $T$. s. elegans, as more than 52 million individuals of this species were imported from the USA between the years 1989 and 1997 and the majority of these ended up in Europe as pets (Cadi et al., 2004). Due to the mass imports, these turtles were sold for relatively low prices and thus were available to almost anyone. When pets are sold to a large number of people, the proportion of those who do not have proper information about their breeding potential and their release into the wild is likely to be high (Fujisaki et al., 2010). High propagule pressure in combination with favourable biotic and abiotic factors can be presumed to explain the successful establishment of $T$. s. elegans in Europe (Ficetola et al., 2009).

There is generally a non-random pattern in the origin of introduced vertebrate species, with most of these coming from the Northern Hemisphere (Jeschke and Strayer, 2006; Kraus, 2009). The majority of pet-trade freshwater turtles (50\%) came to Europe from the Nearctic zoogeographical region. This bias reflects the historical and modern trade connections between Europe and North America (Kraus, 2009). While until the 19th century species introductions from Europe to North America dominated, the reverse was true in the 20th century (Jeschke and Strayer, 2006). Our results confirm the findings of Kraus (2009) and of Wilgen and Richardson (2012) that most pet-trade species among turtles are members of the Emydidae family. This pattern is probably associated with their attractive coloration (Thornhill, 1993). On the other hand, it could be also an artefact of the Emydidae family's origin, because it demonstrates the greatest diversity in North America (Ernst et al., 1994).

While our conclusions about the rankings of establishment risk and their association with family or zoogeographical regions is limited due to the small data set, our results seem relevant for the EU. When looking at the family origins of the most risky species, the most dangerous turtles (i.e. likely to establish if released) are from families other than Emydidae (Chelydra serpentina - Chelydridae, Apalone spinifera - Trionychidae, Pelomedusa subrufa Pelomedusidae, Sternotherus odoratus - Kinosternidae). Due to the absence of family random effect values in Bomford (2008), we compute ranges of potential establishment risk scores for the families Carettochelyidae, Chelidae and Podocnemididae by inserting lowest and highest theoretical values (taken from Bomford 2008) of the family random effect into 
the model formula. It is surprising that the model computations rate no other member of the Emydidae family as serious except $T$. s. elegans that is already established in the EU. This finding suggests that the establishment potential of this family (Wilgen and Richardson, 2012) may be overestimated due only to the success of $T$. s. elegans (see also the Kraus, 2009 database). While taxonomic levels are sometimes useful predictors of establishment success for introduced species (Bomford et al., 2009; Fujisaki et al., 2010), our post hoc comparison for freshwater turtles in the EU pet trade did not confirm that members of particular families have higher risk ranks then others here shown on the Emydidae family.

Establishment risk rank for turtles is not significantly connected with their zoogeographical origin, thus suggesting that particular species' niche breadth plays a more important role in establishment potential. This is consistent with the finding that the most risky species (Chelydra serpentina, Apalone spinifera, Sternotherus odoratus, and Pelomedusa subrufa) exhibit among the most extensive native ranges. Greater range usually means - and especially so in the temperature zone - that a species must face various biotic and abiotic conditions (Angiletta et al., 2004). Since we use the whole territory of the EU as the target region, and as this territory has a large climatic amplitude, it is not surprising that species whose native ranges cover the most distinctive climatic conditions (Kolar and Lodge, 2001) were evaluated as most dangerous.

As in several analogous studies (Thuiller et al., 2005; Bomford et al., 2009; Fujisaki et al., 2010), climate match risk score was the strongest predictor of establishment risk. In agreement with Wilgen et al. (2009), we show that some species have small areas predicted as suitable (e.g. Mauremys reevesii - south Germany, Hydromedusa tectifera - Po Valley in Italy, Chelus fimbriatus - Galicia in Spain) but low average establishment risk score. On the EU maps of climate match risk, some areas appear more frequently as suitable for pet-trade freshwater turtles (Figure 1). These include the vicinity of Rome and Foggia on the west and east coast of central Italy; the Danube Valley in Slovakia, Hungary, Romania and Bulgaria; lowlands of the rivers Maritsa and Tundzha in Bulgaria; and the lowlands of northern Greece. Other important areas are the Po Valley in Italy; the Sava and Krka valleys in Slovenia; as well as the coasts of the Mediterranean Sea of Northern Italy, France and Spain, including Corsica, and Sardinia (compare with Ficetola et al., 2009).

The limitation of presented approach lies in fact, that we used only variables discussed above (prop.species value, family random effect and climate match risk score). Therefore it must be mentioned that establishment-risk scores cannot be viewed as precise estimates of probability for establishment but they rather provide a relative ranking of establishment risk for freshwater turtle species introduced into EU.

Several non-native freshwater turtles in the pet trade have been reported from the wild in EU states, but these findings are rather recent (Burgert et al., 2011). Reproduction in the wild has been confirmed heretofore only for $T$. s. elegans, but this does not necessarily mean that other turtles are not able to reproduce. Reproduction could be easily overlooked (Hulme, 2006) or postponed in time due to the relatively long period in life before turtles reach sexual maturity (de Magalhaes and Costa, 2009). Based on our results we tentatively predict that reproduction will be recorded in the future in the following species: Sternotherus odoratus, Apalone spinifera, Apalone mutica, and Chelydra serpentina. Allee effects can dramatically influence establishment success (Taylor and Hastings, 2005), and the expectation of reproduction in turtles which were (or will be) released in substantial numbers will be also impacted spatially. Copp et al. (2010) demonstrated that urban areas, with their characteristically high population density, are also the most affected by animals introduced from the pet trade. It is noteworthy that after fishes, amphibians and reptiles are relatively invisible to the public when they escape or are released into the wild. These animals have the advantage of more time to establish vital populations before any eradication action comes into force. Therefore, standing waters close to large agglomerations within the suitable climatic regions of the EU should be given greater attention in monitoring. Data from these areas should be evaluated further before any new restrictions will be applied. 


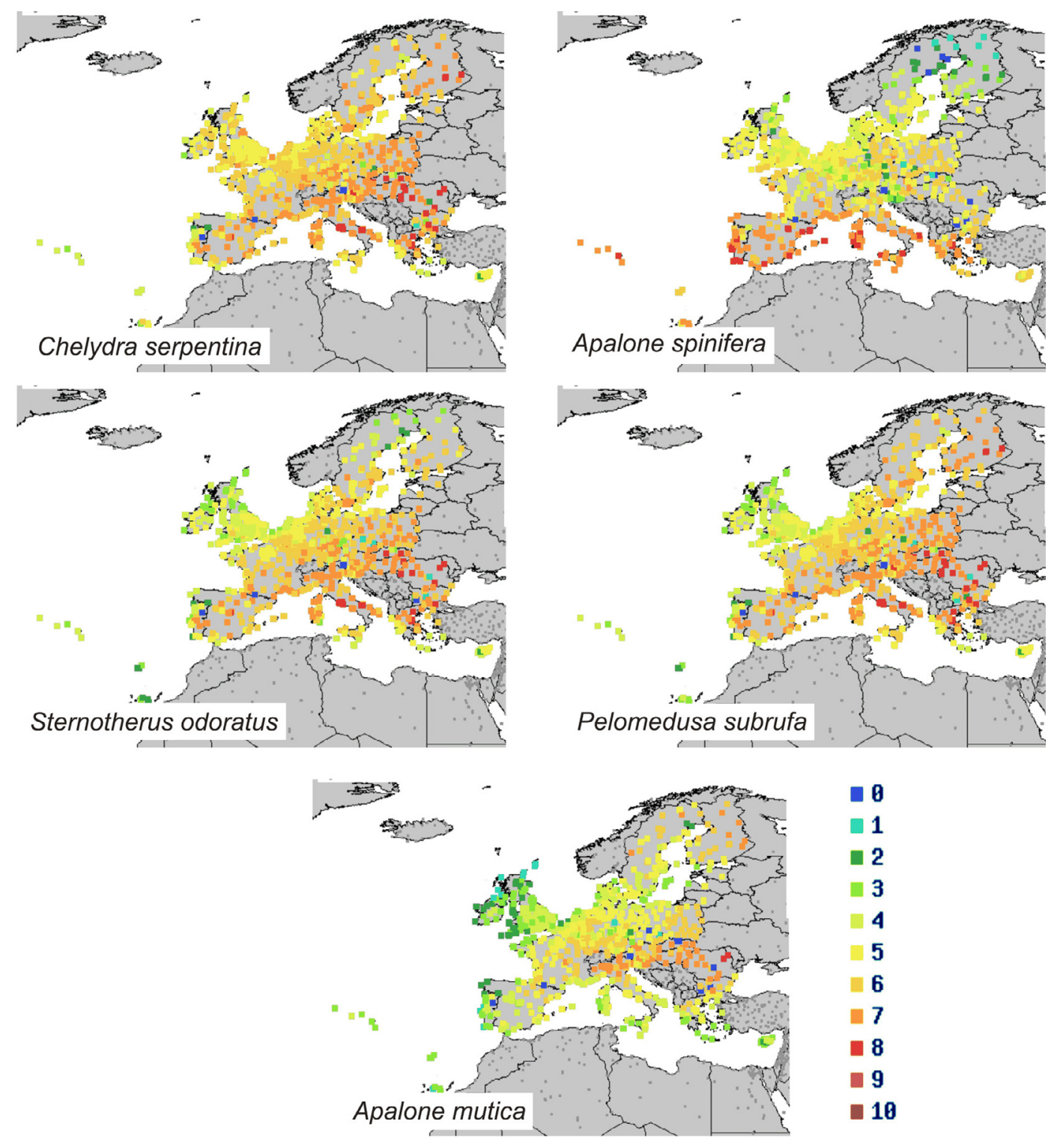

Figure 1

Climate match risk maps showing those places with highest probability of establishment for the five most dangerous species of freshwater turtles (evaluated by model as serious).

\section{ACKNOWLEDGEMENTS}

This work was supported by the Technology Agency of the Czech Republic under grant project TD010045, "Numerická a funkční analýza sektoru akvakultury, včetně rekreačního rybářství, zaměřená na zvýšení konkurenceschopnosti České republiky a zlepšení stavu vodních ekosystémư".

\section{REFERENCES}

Angilletta M.J., Niewiarowski P.H., Dunham A.E., Leaché A.D. and Porter W.P., 2004. Bergmann's clines in ectotherms: illustrating a life-history perspective with sceloporine lizards. Am. Nat., 164, 168-183.

Arnold E.N., 2003. Reptiles and amphibians of Europe. Princeton University Press, Princeton, 198 p. 
Bomford M., 2006. Risk Assessment for the Establishment of Exotic Vertebrates in Australia: Recalibration and Refinement of Models, Bureau of Rural Sciences, Canberra, $130 \mathrm{p}$.

Bomford M., 2008. Risk Assessment Models for Establishment of Exotic Vertebrates in Australia and New Zealand. Invasive Animals Cooperative Research Centre, Canberra, 191 p.

Bomford M., Kraus F., Barry S.C. and Lawrence E., 2009. Predicting establishment success for alien reptiles and amphibians: a role for climate matching. Biol. Invasions, 11, 713-724.

Bureau of Rural Sciences, 2008. Climatch v1.0 software. Bureau of Rural Sciences, Department of Agriculture, Fisheries and Forestry, Canberra, Australia. Available online: http://adl.brs.gov.au: 8080/Climatch/climatch.jsp [Accessed 28.9. 2012].

Burgert R.J.F., Ottburg F.G.W.A., Roessink I., Jansman H.A.H., van der Grift E.A. and Griffioen A.J., 2011. Invasion of the turtles? Exotic turtles in the Netherlands: a risk assessment. Alterra, Wageningen, $95 \mathrm{p}$.

Cadi A. and Joly P., 2003. Competition for basking places between the endangered European pond turtle (Emys orbicularis galloitalica) and the introduced red-eared turtle (Trachemys scripta elegans). Can. J. Zool., 81, 1392-1398.

Cadi A. and Joly P., 2004. Impact of the introduction of the red-eared slider (Trachemys scripta elegans) on survival rates of the European pond turtle (Emys orbicularis). Biodivers. Conserv., 13, 2511-2518.

Cadi A., Delmas V., Prévot-Julliard A.C., Joly P., Pieau C. and Girondot M., 2004. Successful reproduction of the introduced slider turtle (Trachemys scripta elegans) in the south of France. Aquat. Conserv. Mar. Freshw. Ecosyst., 14, 237-246.

Copp G.H., Vilizzi L. and Gozlan R.E., 2010. The demography of introduction pathways, propagule pressure and occurrences of non-native freshwater fish in England. Aquat. Conserv. Mar. Freshw. Ecosyst., 20, 595-601.

DAISIE, 2012. European Invasive Alien Species Gateway. Available online: http://www.europe-aliens. org. [Accessed 5.10. 2012].

Doody J.S., West P., and Georges A., 2003. Beach selection in nesting pig-nosed turtles Carettochelys insculpta. J. Herpetol., 37, 178-182.

Dukes J.S. and Mooney H.A., 1999. Does global change increase the success of biological invaders? Trends Ecol. Evol., 14, 135-139.

EC, 1997. Council Regulation (EC) No 338/97 of 9 December 1996 on the protection of species of wild fauna and flora by regulating trade therein. Official Journal of the European Union L 61 of 3.3.1997, $1-69$.

Ernst C., Lovich J. and Barbour R., 1994. Turtles of the United States and Canada, Smithsonian Institution Press, Washington DC, 578 p.

Ernst R., Massemin D. and Kowarik I., 2011. Non-invasive invaders from the Caribbean: the status of Johnstone's Whistling frog (Eleutherodactylus johnstonei) ten years after its introduction to Western French Guiana. Biol. Invasions, 13, 1767-1777.

Ficetola G.F., Thuiller W. and Padoa-Schioppa E., 2009. From introduction to the establishment of alien species: bioclimatic differences between presence and reproduction localities in the slider turtle. Divers. Distrib., 15, 108-116.

Franke J. and Telecky T.M., 2001. Reptiles as pets. An examination of the trade in live reptiles in the United States. Washington DC, p. 178.

Fritz U. and Havaš P., 2007. Checklist of Chelonians of the World. Vertebrate Zool., 57, 149-368.

Fujisaki I., Hart K.M., Mazzotti F.J., Rice K.G., Snow S. and Rochford M., 2010. Risk assessment of potential invasiveness of exotic reptiles imported to south Florida. Biol. Invasions, 12, 2585-2596.

Guillon J.M., Guéry L., Hulin V., Girondot M., 2012. A large phylogeny of turtles (Testudines) using molecular data. Contrib. Zool., 81, 147-158.

Hayes K.R. and Barry S.C., 2008. Are there any consistent predictros of invasion success? Biol. Invasions, 10, 483-506.

Henderson W., Bomford M. and Cassey P., 2011. Managing the risk of exotic vertebrates incursions in Australia. Wildlife Res., 38, 501-508.

Hulme P.E., 2006. Beyond control: wider implications for the management of biological invasions. J. Appl. Ecol., 43, 835-847. 
Jeschke J.M. and Strayer D.L., 2006. Determinants of vertebrate invasion success in Europe and North America. Glob. Change Biol., 12, 1608-1619.

Kark S., Solarz W., Chiron F., Clergeau P. and Shirley S., 2009. Alien birds, amphibians and reptiles of Europe, Handbook of alien species in Europe, Springer, Dordrecht, $26 \mathrm{p}$.

Keller R.P., Frang K. and Lodge D.M., 2008. Preventing the sprej of invasive species: economic benefits of intervention guided by ecological predictions. Conserv. Biol., 22, 80-88.

Kolar C. and Lodge D.M., 2001. Progress in invasion biology: predicting invaders. Trends Ecol. Evol., 16, 199-204.

Kraus F., 2009. Alien Reptiles and Amphibians: a Scientific Compendium and Analysis. Springer, New York, $576 \mathrm{p}$.

Livengood E.J. and Chapman F.A., 2007. The ornamental fish trade: An introduction with perspectives for responsible aquarium fish ownership. University of Florida IFAS, Gainesville, $124 \mathrm{p}$.

Lockwood J.L., Cassey P. and Blackburn T., 2005. The role of propagule pressure in explaining species invasions. Trends Ecol. Evol., 20, 223-228.

Mack R., Simberloff D., Lonsdale W., Evans H., Clout M. and Bazzaz F., 2000. Biotic invasions: causes, epidemiology, global consequences, and control. Ecol. Appl., 10, 689-710.

de Magalhaes J.P. and Costa J., 2009. A database of vertebrate longevity records and their relation to other life-history traits. J. Evol. Biol., 22, 1770-1774.

Manchester S.J. and Bullock J.M., 2000. The impacts of non-native species on UK biodiversity and the effectiveness of control. J. Appl. Ecol., 37, 845-864.

Martínez-Silvestre A., Soler J., Solé R., González F.X. and Sampere X., 1997. Nota sobre la reproducción en condiciones naturales de la tortuga de Florida (Trachemys scripta elegans) en Masquefa (Cataluña, España). Boletín de la Asociación Herpetológica Española, 8, 40-42.

McGuire C. and Marnell F., 2000. The present status of the slow-worm, Anguis fragilis L., in Ireland. Bull. Irish Biogeogr. Soc., 24, 69-74.

Miller-Morgan T., 2009. A Brief Overview of Ornamental Fish Industry and Hobby. In: Roberts H.E. (ed.), Fundamentals of Ornamental Fish Helath, Blackwell Publishing, New York, 25-32.

Mlíkovský J. and Stýblo P., 2006. Nepůvodní druhy fauny a flóry České republiky. ČsOP, Praha, 496 p.

Peay S., 2009. Invasive non-indigenous crayfish species in Europe: Recommendations on managing them. Knowl. Managt. Aquat. Ecosyst., 394-395, 1-9.

Pešát J., 2008. Želvy ohrožují hnízdění vodního ptactva. Živa 5, 229.

Pimentel D., Zuniga R. and Morrison D. 2005. Update on the environmental and economic costs associated with alien-invasive species in the United States. Ecol. Econ., 52, 273-288.

Polo-Cavia N., López P. and Martín J., 2008. Interspecific Differences in Responses to Predation Risk May Confer Competitive Advantages to Invasive Freshwater Turtle Species. Ethology, 114, 115-123.

Proches S., Wilson J.R.U., Richardson D.M. and Rejmánek M., 2008. Searching for phylogenetic pattern in biological invasions. Glob. Ecol. Biogeogr., 17, 5-10.

Pyšek P., Bacher S., Chytrý M., Jarošík V., Wild J., Celesti-Grapow L., Gassó N., Kenis M., Lambdon P.W., Nentwig W., Pergl J., Roques A., Sádlo J., Solarz W., Vilà M. and Hulme P.E., 2010. Contrasting patterns in the invasions of European terrestrial and freshwater habitats by alien plants, insects and vertebrates. Glob. Ecol. Biogeogr., 19, 317-331.

Ricciardi A., 2007. Are modern biological invasions an unprecedented form of global change? Conserv. Biol., 21, 329-336.

Sindaco R., Doria G., Razzetti E. and Bernini F., 2006. Atlas of Italian amphibians and reptiles, Polistampa, Firenze, $792 \mathrm{p}$.

Simberloff D., 2009. The role of propagule pressure in biological invasions. Ann. Rev. Ecol. Evol. Syst., 40, 81-102.

Statsoft Inc., 2010. Electronic Statistics textbook. Tulsa (StatSoft), USA.

Strauss S.Y., Webb C.O. and Salamin N., 2006. Exotic taxa less related to native species are more invasive. Proc. Natl. Acad. Sci. USA, 103, 5841-5845.

Strayer D.L., Evinver V.T., Jeschke J.M. and Pace M.L., 2006. Understanding the long-term effects of species invasions. Trends Ecol. Evol., 21, 645-651. 
Taylor C.M. and Hastings A., 2005. Allee effects in biological invasions. Ecol. Lett., 8, 895-908.

Teillac-Deschamps P. and Prevot-Julliard A.C., 2006. Impact of exotic slider turtles on freshwater communities: an experimental approach. First European congress of conservation biology, book of abstracts. Society for Conservation Biology, Heger, p. 162-163.

Thornhill R., 1993. Darwinian aesthetics informs traditional aesthetics. In: Kellert S.R and Wilson E.Q. (eds.), The biophilia hypothesis, Island Press, Washington, 9-35.

Thuiller W., Richardson D., Pyšek P., Midgley G., Hughes G. and Rouget M., 2005. Niche based modelling as a tool for predicting the risk of alien plant invasions at a global scale. Glob. Change Biol., $11,2234-2250$.

van Wilgen N.J. and Richardson D.M., 2012. The role of climate, phylogenetic relatedness, introduction effort, and reproducitove traits in the establishment of non-native reptiles and amphibians. Conserv. Biol., 26, 267-277.

van Wilgen N.J., Roura-Pascual N., and Richardson D.M. 2009. A quantitative climate-match score for risk-assessment screening of reptile \& amphibian introductions. Environ. Manag., 44, 590-607.

Williamson M., 1996. Biological Invasions, Chapman and Hall, London, $244 \mathrm{p}$.

Zhou Z. and Jiang Z., 2008. Characteristics and Risk Assessment of International Trade in Tortoises and Freshwater Turtles in China. Chelon. Conserv. Biol., 7, 28-36. 